\title{
KAJIAN EKSTERNALITAS DAN KEBERLANJUTAN PERIKANAN DI PERAIRAN WADUK JATILUHUR
}

\author{
Sonny Koeshendrajana', Rizki Aprilian Wijaya', Fatriyandi Nur Priyatna', \\ Pujoyuwono Martosuyono ${ }^{1}$ dan Sutrisno Sukimin ${ }^{2}$ \\ ${ }^{1}$ Peneliti pada Balai Besar Riset Sosial Ekonomi Kelautan dan Perikanan \\ JI. KS. Tubun Petamburan VI, Jakarta 10260 \\ Telp. 021 53650162/Fax. 02153650159 \\ ${ }^{2}$ Dosen Manajemen Sumberdaya Perikanan, Fakultas Perikanan dan IImu Kelautan - IPB
}

\begin{abstract}
ABSTRAK
Eksternalitas dapat diartikan sebagai dampak dari suatu kegiatan tertentu terhadap kegiatan lainnya. Dalam konteks pengelolaan sumberdaya perairan, eksternalitas sangat penting diketahui mengingat hal tersebut dapat menyebabkan terjadinya alokasi pemanfaatan sumberdaya yang tidak efisien dan selanjutnya mempengaruhi kinerja keberlanjutan pemanfaatannya. Oleh karena itu, penelitian bertujuan mengkaji eksternalitas dan status keberlanjutan perikanan pada sumberdaya perairan waduk di waduk Jatiluhur. Penelitian ini dilakukan selama bulan Juli-Desember 2009. Secara spesifik, kegiatan penelitian difokuskan untuk mendapatkan data dinamika pengelolaan perikanan, eksternalitas dan status keberlanjutan pola pengelolaan perikanannya. Studi kasus digunakan pada penelitian ini. Data primer diperoleh melalui survei lapang dan data sekunder diperoleh melalui penelusuran dan kajian literatur terkait topik penelitian. Metoda analisis deskriptif kualitatif dan tabulatif digunakan dalam penelitian ini. Hasil penelitian menyajikan gambaran dinamika pengelolaan perikanan yang ada. Eksternalitas dan status keberlanjutan pola pengelolaan perikanan yang ada dieksplorasi berdasarkan lima pelaku pemanfaat yang teridentifikasi, yaitu perikanan tangkap, perikanan budidaya, wisata pemancingan, transportasi dan manajemen waduk. Keberlanjutan bagi pemanfaatan perikanan waduk dapat terjamin apabila pelaku usaha melakukan optimalisasi sesuai dengan daya dukung perairan bagi perikanan budidaya dan menjalankan pilihan pengelolaan perikanan tangkap dalam bentuk penerapan alat dan metoda penangkapan yang ramah lingkungan, penebaran ikan yang dapat memanfaatkan kesuburan perairan. Hasil kajian dapat digunakan oleh otoritas pengelola waduk sebagai rujukan bagi rumusan kebijakan pengelolaan perikanan di waduk Jatiluhur.
\end{abstract}

Kata Kunci: Eksternalitas, Keberlanjutan, Perikanan, Waduk, Jatiluhur.

Abstract: Externality and Sustainablity of Fisheries in the Jatiluhur Reservoir. By: Sonny
Koeshendrajana1), Rizki Aprilian Wijaya1), Fatriyandi Nur Priyatna", Pujoyuwono
Martosuyono"and Sutrisno Sukimin

Externality can be defined as an impact of a certain activity to other activity. In the context of fisheries resource management, externality is important to understand due to its impact on in-efficiency resource allocation, and hence, affecting to the sustainable use of the resource. Therefore, research aimed at exploring externalities and sustainability status of fisheries in the Jatiluhur reservoir was carried out during July - December 2009. Specifically, the research was focused to find the dynamic pattern of fisheries related activities, externalities and sustainability status of the fisheries management pattern. Case study method was used in this study. Primary and secondary data were used in this study. Primary data were collected through field survey while secondary data were collected through literatures review on the relatedtopic of the study. Analyses were carried out descriptively both qualitative and tabulative data and information. Results of the study show dynamic illustration of the fisheries management practices in the Jatiluhur reservoir resource. Externalities and sustainability status of fisheries management pattern were explored based on five players being identified, namely capture fishery, aquaculture, sport fishing, transportation and reservoir management. Sustainability of each activity could be maintained if fish farmers 
operate cage culture optimally in accordance with the carrying capacity of the resource while fishery management implements the appropriated fishing gears and methods as well as stocking recommended species of fish to utilize the abundance of natural food. The results can be used by management authority as a basis for formulating policy and strategy fisheries management practice in the Jatiluhur reservoir.

Keywords: Externality, Sustainability, Fisheries, Reservoir, Jatiluhur.

\section{PENDAHULUAN}

Sumberdaya kelautan dan perikanan merupakan sumberdaya yang bersifat dinamis, baik dengan ataupun tanpa intervensi dari manusia selaku pemanfaat sumberdaya. Sebagai ilustrasi, pada sumberdaya perikanan tangkap, secara sederhana dinamika stok ikan ditunjukkan oleh keseimbangan yang disebabkan oleh pertumbuhan stok, baik sebagai akibat dari pertumbuhan individu (individual growth) maupun oleh perkembangbiakkan (recruitment) stok itu sendiri. Dengan keterbatasan daya dukung lingkungan sumberdaya di lokasi tersebut, maka stok ikan akan mengalami pengurangan sebagai akibat dari kematian alami (natural mortality) sampai keseimbangan stok ikan sesuai daya dukungnya. Adanya intervensi manusia dalam bentuk aktivitas penangkapan (fishing activity) pada hakekatnya adalah memanfaatkan 'bagian' dari kematian alami, dengan catatan bahwa aktivitas penangkapan yang dilakukan dapat dikendalikan sampai batas kemampuan pemulihan stok secara alami (Koeshendrajana, 2007).

Salah satu sumberdaya perairan umum daratan adalah berupa waduk yang mempunyai potensi strategis dan manfaatnya bersifat serbaguna baik secara ekologis maupun ekonomis. Selain fungsi utama waduk untuk pembangkit listrik tenaga air (PLTA), irigasi dan pencegah banjir, perairan waduk dapat dimanfaatkan untuk transportasi, rumah tangga, perikanan (baik perikanan budidaya maupun perikanan tangkap) dan pariwisata. Saat ini kelestarian fungsi perairan waduk terganggu oleh masalah-masalah pendangkalan (sedimentasi), pencemaran, eutrofikasi maupun perubahan fungsi. Gangguan ini dapat berasal dari wilayah hulu, akibat tidak diperhatikannya masalah konservasi hutan dan lahan/tanah, sehingga menimbulkan erosi tanah yang menyebabkan pendangkalan waduk, pencemaran limbah rumah tangga, industri dan pertanian (faktor eksternal) yang masuk ke perairan waduk, di samping itu, gangguan juga dapat berasal dari pemanfaatan perairan waduk itu sendiri (faktor internal).

Pengelolaan perikanan pada sumberdaya perairan waduk sampai dengan saat ini masih berorientasi pada produksi untuk meningkatkan keuntungan secara ekonomi. Secara umum perkembangan karamba jaring apung (KJA) yang pesat berdampak positif terhadap peningkatan produksi ikan air tawar dan pendapatan pembudidaya. Namun demikian, peningkatan jumlah unit KJA yang tidak terkendali telah menimbulkan berbagai masalah yang berdampak negatif, baik secara ekonomi maupun terhadap lingkungan perairan, termasuk terhadap perikanan tangkap perairan waduk (Nasution et al., 2008). Seperti limbah organik yang bulky akibat ketidakefisienan pakan yang diberikan akan menumpuk di dasar kemudian terjadi eutrofikasi yang menyebabkan blooming alga diikuti dengan munculnya gas-gas yang dapat membunuh organisme lain yang ada. Dalam keadaan demikian maka secara fisik waduk tersebut tidak akan jauh berbeda dengan comberan raksasa, di waktu mendapatkan sinar matahari berwarna hijau pekat dan berwarna hitam kecoklat-coklatan di saat tidak 
mendapatkan sinar matahari. Dampak tersebut tentu saja merugikan petani dan nelayan ikan, di samping itu berdampak juga terhadap pariwisata dan sumber air untuk konsumsi (Adibroto dan Garno, 1999).

Dampak negatif maupun positif yang terjadi akibat aktivitas pengelolaan perikanan di waduk merupakan salah satu dampak adanya eksternalitas. Eksternalitas secara umum dapat diartikan sebagai dampak dari suatu suatu aktivitas atau tindakan (pihak pertama) terhadap aktivitas atau tindakan (pihak lain). Terkait dengan pemanfaatan sumberdaya perairan, maka secara eksternalitas dapat diartikan sebagai dampak dari suatu kegiatan produksi tertentu terhadap utilitas atau nilai kegunaan dari kegiatan lain yang tidak diinginkan. Dalam konteks pengelolaan sumberdaya perairan, eksternalitas sangat penting diketahui mengingat hal tersebut akan menyebabkan terjadinya alokasi pemanfaatan sumberdaya yang tidak efisien.

Pengertian eksternalitas dapat dilihat dari berbagai sudut pandang, misalnya Friedman (1990) mengklasifikasikan ekternalitas terkait dengan barang publik. Sedangkan Kula (1992) dan Fauzi (2004), mengelompokkan eksternalitas dalam bentuk ekternalitas teknologi dan eksternalitas pecuniary. Di lain pihak, eksternalitas privat dan publik diperkenalkan oleh Hartwick dan Olewiler (1998). Secara ekonomi, sebenarnya timbulnya eksternalitas secara implisit memberikan petunjuk bahwa mekanisme pasar berjalan dengan tidak sempurna. Fauzi (2004) memberikan ilustrasi bahwa pada kasus sumberdaya berupa barang publik, misalnya pencemaran udara sebagai akibat aktivitas/tindakan pihak pertama yang dirasakan oleh pihak lain, memberikan contoh bahwa transaksi pasar tidak berjalan karena bila pasar bekerja dengan sempurna, pelaku penyebab pencemaran seharusnya membayar kompensasi kepada pihak lain yang terkena pencemaran. Lebih lanjut, tipologi eksternalitas dapat dilihat pada Fauzi (2004).
Selama ini, informasi terkait dengan eksternalitas sebagai akibat aktivitas perikanan di suatu tipologi sumberdaya perairan umum daratan belum banyak diungkapkan oleh peneliti. Selain itu, status keberlanjutan aktivitas perikanan di suatu tipologi sumberdaya perairan umum daratan juga belum banyak mendapat perhatian para peneliti. Berdasarkan uraian tersebut maka permasalahan yang akan dianalisis pada penelitian ini adalah aktivitas perikanan budidaya dan perikanan tangkap di Waduk Jatiluhur yang menimbulkan eksternalitas (dampak sampingan) terhadap lingkungan dan aktivitas perikanan itu sendiri. Oleh karena itu, fokus penelitian ini adalah untuk mengkaji eksternalitas dan keberlanjutan aktivitas perikanan di satu tipologi sumberdaya perairan umum daratan, yakni di perairan Waduk Jatiluhur.

\section{METODOLOGI}

\section{Ruang Lingkup}

Eksternalitas dan keberlanjutan perikanan di perairan waduk merupakan studi yang bersifat antisipatif. Pengelolaan perikanan pada sumberdaya perairan waduk sampai saat ini masih berorientasi kepada produksi untuk meningkatkan keuntungan secara ekonomi, kurang atau bahkan tidak memperhitungkan kerusakan lingkungan perairan yang terjadi sebagai akibat pilihan pengelolaan perikanan yang dipraktekkan tersebut. Kerusakan lingkungan yang terjadi secara terus menerus, pada akhirnya akan mengganggu aktivitas ekonomi masyarakat perikanan di perairan waduk itu sendiri. Segala aktivitas ekonomi perikanan di perairan Waduk Jatiluhur pada saat ini telah mengarah kepada meningkatnya permasalahan baik secara ekologis maupun secara ekonomi. Permasalahan tersebut diantaranya adalah penggunaan alat tangkap yang tidak ramah lingkungan, kegiatan budidaya yang melebihi daya dukung, dan konflik-konflik yang terjadi diantara pelaku perikanan. Pada akhirnya, keberlanjutan perikanan di perairan waduk 
pada masa-masa mendatang mengalami gangguan yang serius.

Dalam penelitian ini, dinamika pengelolaan sumberdaya perairan waduk dikaji berdasarkan data produksi dan perkembangan pelaku perikanan selama kurun waktu tertentu. Basis data dinamika pengelolaan tersebut dapat dijabarkan menjadi identifikasi eksternalitas pelaku usaha ekonomi di perairan. Penentuan bentuk eksternalitas sebagai akibat kegiatan satu terhadap kegiatan yang lain dilakukan melalui proses diskusi tim peneliti dan verifikasi hasil diskusi ke lapang kepada responden kunci, baik penentu kebijakan (Pemda Kabupaten Purwakarta, Dinas Perikanan dan Perum Jasa Tirta II), kelompok nelayan, pembudidaya ikan, agen pakan dan pedagang.

\section{Lokasi Penelitian}

Lokasi penelitian berada di Waduk Jatiluhur sebagai salah satu waduk yang digunakan untuk kegiatan produksi ikan, baik dari kegiatan budidaya maupun penangkapan.

\section{Data dan Sumber Data}

Data primer dan data sekunder digunakan dalam penelitian ini. Penelitian ini fokus kepada pencarian data sekunder yang terkait dengan eksternalitas perikanan di Waduk Jatiluhur yang kemudian dilakukan verifikasi lapang terkait dengan datayang telah dikumpulkan. Data primer yang dikumpulkan berupa verifikasi hasil diskusi tim dan data sekunder yang diperoleh kepada responden kunci. Responden kunci yang dimaksudkan adalah Pemda Kabupaten Purwakarta, Dinas Perikanan Kabupaten Purwakarta, Perum Jasa Tirta II (PJT II), Loka Riset Pemacuan Stok Ikan Jatiluhur, Dinas Lingkungan Hidup Kabupaten Purwakarta, dan Himpunan Pengusaha Jaring Terapung. Di samping itu, wawancara dilakukan terhadap kelompok nelayan, pembudidaya ikan, bandar (pedagang ikan) dan agen pakan di lokasi penelitian. Data sekunder yang dikumpulkan meliputi statistik, data dan informasi serta hasil-hasil penelitian yang terkait dengan eksternalitas perikanan di perairan Waduk Jatiluhur.

\section{Metoda Analisis}

Analisis dilakukan secara deskriptif kualitatif dan tabulatif. Secara ringkas, keterkaitan tujuan/sasaran, jenis dan sumber data, metoda pengumpulan dan analisis data disajikan pada Tabel 1 .

\section{HASIL DAN PEMBAHASAN}

\section{Karakteristik Sumberdaya Perairan dan Pekembangan Waduk Jatiluhur}

Waduk adalah wadah buatan yang terbentuk sebagai akibat dibangunnya bendungan yang mempunyai sifat perairan air diam (tergenang), debit air fluktuatif dengan pola relatif tetap/konstan dan umumnya berair sepanjang tahun. Waduk Ir. H. Djuanda atau yang lebih dikenal dengan nama Waduk Jatiluhur dibangun pada awal tahun 1957 dan dinyatakan selesai pada tahun 1967 serta kemudian dikelola oleh Perusahaan Negara (PN) Jatiluhur (1967 - 1970). Waduk Jatiluhur terletak pada Kabupaten Purwakarta, Provinsi Jawa Barat. Pemerintah melalui Peraturan Pemerintah (PP) nomor 94 tahun 1999 tentang pengelolaan, perlindungan, pemanfaatan dan pengembangan waduk Jatiluhur membentuk badan otorita pengelola yaitu Perum Jasa Tirta II (PJT II). Berdasarkan PP tersebut kewenangan PJT II yaitu sebagai BUMN pengelola air dan atau sumber air.

Waduk Jatiluhur mempunyai luas 8.300 Ha dengan kapasitas waduk mencapai \pm 3 Milyar $\mathrm{m}^{3}$ dan duga muka air maksimum mencapai \pm 107 meter di atas permukaan laut (dpl). Waduk ini merupakan waduk serbaguna dengan peruntukkan utama untuk Pembangkit Listrik Tenaga Air (PLTA), penyediaan baku air minum dan industri dan penyediaan air irigasi. Selain itu, waduk ini juga dimanfaatkan bagi perikanan, pariwisata dan pengendalian banjir. Sumber air waduk Jatiluhur berasal dari Daerah Aliran Sungai (DAS) Citarum yaitu, daerah pengaliran waduk Saguling dan Cirata. 
Tabel 1. Keterkaitan Tujuan, Jenis dan Sumber Data, Metoda Pengumpulan dan Analisis
Data Kajian Eksternalitas dan Keberlanjutan Perikanan Waduk Jatiluhur, 2009.

Table 1. Inter-correlation of the Objectives, Type of Data, Source of Data, Collecting and Analyses Methods of the Study on Externality and Sustainability of Fisheries in the Jatiluhur's Reservoir, 2009.

\begin{tabular}{|c|c|c|c|c|}
\hline $\begin{array}{c}\text { Tujuan dan Sasaran / } \\
\text { Objectives and } \\
\text { Target }\end{array}$ & $\begin{array}{c}\text { Jenis Data / Type of } \\
\text { Data }\end{array}$ & $\begin{array}{l}\text { Sumber Data / } \\
\text { Source of Data }\end{array}$ & $\begin{array}{c}\text { Metoda } \\
\text { Pengumpulan / } \\
\text { Collecting Method }\end{array}$ & $\begin{array}{l}\text { Metoda Analisis / } \\
\text { Analysis Method }\end{array}$ \\
\hline $\begin{array}{l}\text { Mendapatkan data } \\
\text { dinamika pengelolaan } \\
\text { perikanan waduk } \\
\text { Jatiluhur / To find data } \\
\text { on dynamics of the } \\
\text { Jatiluhur's reservoir } \\
\text { fisheries management }\end{array}$ & $\begin{array}{l}\text { - Karakteristik } \\
\text { sumberdaya perairan } \\
\text { dan perkembangan } \\
\text { waduk Jatiluhur } \\
\text { /Characteristics of the } \\
\text { Jatilluhur's reservoir } \\
\text { resource and its } \\
\text { developmnet } \\
\text { - Dinamika } \\
\text { pengelolaan } \\
\text { perikanan tangkap } \\
\text { dan budidaya / } \\
\text { Dynamic of capture } \\
\text { and culture fisheries } \\
\text { management }\end{array}$ & $\begin{array}{l}\text { Laporan Dinas } \\
\text { terkait, statistik } \\
\text { dan hasil-hasil } \\
\text { penelitian terkait } \\
\text { topik kajian / } \\
\text { Institutional reports } \\
\text { related to statistics } \\
\text { and research } \\
\text { results related to } \\
\text { the topic study }\end{array}$ & $\begin{array}{l}\text { Penelusuran literatur / } \\
\text { Literature review }\end{array}$ & $\begin{array}{l}\text { Deskriptif kualitatif } \\
\text { dan tabulasi } \\
\text { silang / Descriptive } \\
\text { qualitative and } \\
\text { cross-tabulated } \\
\text { analyses }\end{array}$ \\
\hline $\begin{array}{l}\text { Mendapatkan data } \\
\text { eksternalitas pelaku } \\
\text { usaha teridentifikasi / } \\
\text { To find data on } \\
\text { externality of identified } \\
\text { practical user }\end{array}$ & $\begin{array}{l}\text { Pelaku usaha } \\
\text { ekonomi di waduk } \\
\text { Jatiluhur serta } \\
\text { eksternalitasnya / } \\
\text { Practical economic } \\
\text { user in the Jatiluhur's } \\
\text { reservoir and its } \\
\text { externality }\end{array}$ & $\begin{array}{l}\text { Diskusi Tim dan } \\
\text { verifikasi lapang / } \\
\text { Team work } \\
\text { discussion and field } \\
\text { verification }\end{array}$ & $\begin{array}{l}\text { Diskusi tim, } \\
\text { wawancara dengan } \\
\text { responden kunci / } \\
\text { Team work } \\
\text { discussion, interview } \\
\text { with key respondents }\end{array}$ & $\begin{array}{l}\text { Tabulasi dalam } \\
\text { bentuk matrik dan } \\
\text { interpretasi } \\
\text { deskriptif / } \\
\text { Tabulation in the } \\
\text { matrix form and its } \\
\text { descriptive } \\
\text { interpretation }\end{array}$ \\
\hline $\begin{array}{l}\text { Mengkaji data status } \\
\text { keberlanjutan } \\
\text { perikanan waduk } \\
\text { Jatiluhur / To study on } \\
\text { sustainability status of } \\
\text { fisheries in the } \\
\text { Jatiluhur's reservoir }\end{array}$ & $\begin{array}{l}\text { Manfaat ekonomi, } \\
\text { sosio-politik dan } \\
\text { lingkungan / } \\
\text { Economic, socio- } \\
\text { political and } \\
\text { environmental } \\
\text { benefits }\end{array}$ & $\begin{array}{l}\text { Hasil-hasil } \\
\text { penelitian dan } \\
\text { verifikasi lapang / } \\
\text { Research results } \\
\text { and their field } \\
\text { verification }\end{array}$ & $\begin{array}{l}\text { Diskusi tim, } \\
\text { wawancara dengan } \\
\text { responden kunci / } \\
\text { Team work } \\
\text { discussion, interview } \\
\text { with key respondents }\end{array}$ & $\begin{array}{l}\text { Deskriptif kualitatif/ } \\
\text { Descriptive } \\
\text { qualitative analysis }\end{array}$ \\
\hline
\end{tabular}

Karakteristik perairan waduk Jatiluhur sebagaimana dikompilasi oleh Prihadi (2004) adalah seperti disajikan pada Tabel 2. Namun, kondisi tersebut secara dinamis mengalami perubahan seperti kedalaman rata-rata yang sepanjang tahun 2003 mengalami penurunan menjadi $26,2 \mathrm{~m}$, terlebih lagi pada bulan Agustus-September kedalaman rata rata mencapai $23,7 \mathrm{~m}$ sebagai akibat kemarau yang berkepanjangan, sehingga volume air berkurang hingga 30\% dari keadaan normal sebelumnya.

Sebagaimana digambarkan oleh proses pembentukkannya, waduk atau danau buatan merupakan hasil pembendungan sungai, sehingga akan terjadi perubahan dari ekosistem mengalir (riverine ecosystem) menjadi ekosistem tergenang (lacustrine ecosystem). Akibat terjadinya perubahan ekosistem, maka akan terjadi akumulasi bahan nutrien ke perairan dan dengan bertambahnya umur waduk, maka akan terjadi perubahan status trofik dari oligotrof menjadi mesotrof. Apabila bahan organik yang masuk ke perairan sangat besar (baik berasal dari anthrophogenik maupun internal), maka perairan akan mencapai eutrof dan bahkan dapat mencapai hyper-eutrof. Pada saat ini, 
Tabel 2. Karakteristik Sumberdaya Perairan Waduk Jatiluhur.

Table 2. Characteristics of the Jatiluhur's Reservoir Resource.

\begin{tabular}{lc}
\multicolumn{1}{c}{ Kategori/Category } & Nilai atau Status/Value or \\
& Status \\
\hline Ketinggian dari muka laut (m)/ High above sea water level $(\mathrm{m})$ & 111 \\
Volume air x $1000 \mathrm{~m}^{3}$ / Water volume & 2.970 .000 \\
Luas permukaan (A), ha / Area of water surface & 8.300 \\
Kedalaman rata-rata (m) / Average depth & 35,8 \\
Kedalaman maksimum ( $Z_{\text {maks }}$ ), m / Max depth & 90 \\
Status kesuburan/Trophic level status & Mesotrophic-Eutrophic \\
Pola pencampuran massa air / Pattern of water dissolve & Oligomictic (rare) \\
Rasio A/ Z $Z_{\text {maks }}$ / Ratio A/ $Z_{\text {maks }}$ & 0,92 \\
Kondisi tanpa oksigen dimulai pada lapisan kedalaman $(\mathrm{m}) /$ & 11 -20 (anoxic) \\
Anoxic condition depth & \\
\hline
\end{tabular}

Sumber: Prihadi (2004) / Source: Prihadi (2004).

status trofik perairan di waduk Jatiluhur sudah mencapai eutrof-hypertrof.

Berdasarkan klasifikasi tingkat kesuburan perairan berdasarkan unsur hara dan biomassa fitoplankton (chlorophyl-a). Waduk Jatiluhur memiliki status trofik mesotropik sampai dengan eutropik. Tabel 3 menunjukkan rata-rata kandungan unsur hara dan biomassa fitoplankton (chlorophyl-a) di waduk Jatiluhur.

Berdasarkan parameter kimia-fisika kualitas air di Waduk Jatiluhur secara umum terlihat bahwa kandungan kualitas air bertendensi pencemaran, hal ini terlihat dari data asam sulfida $\left(\mathrm{H}_{2} \mathrm{~S}\right)$ hingga mencapai 6,7 ppm padahal baku mutu air untuk perikanan hanya sebesar 0,01 ppm selain itu kondisi tersebut akan menimbulkan karat pada turbin, bahan racun pada saat upwelling dan blooming algae seperti jenis Microcystis sp. (Tabel 4).

\section{Dinamika Pengelolaan Perikanan Tangkap dan Budidaya di Waduk Jatiluhur \\ Populasi ikan di Waduk Jatiluhur tidak} banyak pada awal pembendungan karena jenis-jenis ikan rheophylic yang berasal dari sungai tidak dapat beradaptasi di ekosistem

Tabel3. Rata-rata Kandungan Unsur Hara dan Biomassa Fitoplankton (chlorophyl-a) di Waduk Jatiluhur.

Table 3. Average Nutrients and Phytoplankton ((chlorophyl-a) Biomass Content in the Jatiluhur's Reservoir.

\begin{tabular}{llcc}
\hline \multicolumn{1}{c}{ Parameter / Parameters } & $\begin{array}{c}\text { Mesotrof / } \\
\text { Mesotroph }\end{array}$ & $\begin{array}{c}\text { Eutrof / } \\
\text { Eutroph }\end{array}$ \\
\hline Rataan total N /Average total N $(\mu \mathrm{g} / \mathrm{l})$ & 753 & 1875 \\
Rataan total P /Average total P $\quad(\mu \mathrm{g} / \mathrm{l})$ & 26,7 & 84,4 \\
Rataan / Average chlorophyl -a $(\mu \mathrm{g} / \mathrm{l})$ & 4,7 & 14,3 \\
Konsentrasi / Concentration chlorophyl - a $(\mu \mathrm{g} / \mathrm{l})$ & 16,1 & 42,6 \\
\hline
\end{tabular}

Sumber: DKP \& ACIAR (2007)/Source: MMAF and ACIAR (2007) 
Tabel 4. Karakteristik Kualitas Air di Perairan Waduk Jatiluhur.

Table 4. Characteristics of Water Quality in the Jatiluhur's Reservoir.

\author{
Variabel Kualitas Air/ \\ Variable of Water Quality
}

Nilai / Value

\begin{tabular}{|c|c|}
\hline Oksigen terlarut/Disolved Oxygene(mg/L) & $6,5-9,0(7,5 \pm 0,1)$ \\
\hline Bahan organik/Organic matter KMnO 4 (mg/L) & $2-99$ \\
\hline $\mathrm{NO}_{3}($ nitrate) $(\mathrm{ml} / \mathrm{L})$ & $0,003-1,100(0,235 \pm 0,0236)$ \\
\hline $\begin{array}{l}\text { Alkalinitas (mg CaCO3/L) } \\
\mathrm{NH}_{4} \text { (amonia) (ml/L) }\end{array}$ & $\begin{array}{c}24,31-92,82(47,84 \pm 2,24) \\
0,057-1,723(0,708 \pm 0,069)\end{array}$ \\
\hline $\mathrm{NO}_{2}$ (Nitrite) $(\mathrm{ml} / \mathrm{L})$ & $0,01-1,74(0,332 \pm 0,57)$ \\
\hline Total P (pospor) (ml/L) & $0,576-1,164(0,881 \pm 0,025)$ \\
\hline $\mathrm{PO}_{4}$ (phospate) (ml/L) & $0,015-1,725(0,582 \pm 0,041)$ \\
\hline $\mathrm{H}_{2} \mathrm{~S}(\mathrm{ppm})$ & $0,21-6,7$ \\
\hline Mg (magnesium) & $49,71-164,80(70,23 \pm 5,60)$ \\
\hline $\mathrm{Hg}$ (air raksa) mg/l & $0,002-0,018$ \\
\hline $\mathrm{Pb}$ (Plumbum) & $0,01-0,310$ \\
\hline $\mathrm{Zn}^{2+}$ & $0,032-0,316$ \\
\hline Mn mg/l & $0,02-0,11$ \\
\hline $\begin{array}{l}\mathrm{Cr} \\
\mathrm{Fe}\end{array}$ & $\begin{array}{c}0,002-0,015 \\
0,01-0,17\end{array}$ \\
\hline $\begin{array}{l}\mathrm{Cu} \\
\mathrm{Cd} \mathrm{mg} / \mathrm{l}\end{array}$ & $\begin{array}{c}0,00-0,01 \\
0,002-0,011\end{array}$ \\
\hline Keasaman Acidity (pH) & $6,6-9,2$ \\
\hline Kecerahan air/ Water turbidity (cm) & $80-140(114 \pm 7)$ \\
\hline Suhu / Temperature $\left({ }^{\circ} \mathrm{C}\right)$ & $28,0-33,5$ \\
\hline
\end{tabular}

Sumber: Prihadi (2004) / Source: Prihadi (2004).

tergenang (waduk) dimana perairan cenderung dalam dan kandungan oksigen terlarut lebih rendah dibandingkan ekosistem mengalir akibat pola stratifikasi yang terjadi di ekosistem perairan tergenang. Seiring dengan berkembangannya umur waduk, untuk tujuan peningkatan produksi ikan maka dilakukan introduksi atau stocking-restocking beberapa jenis ikan tertentu yang mampu memanfaaatkan relung di perairan waduk.

Keanekaragaman hayati perairan dapat menunjukkan keragaman dan kelimpahan organisme perairan di suatu ekosistem tertentu yang terdiri dari tanaman, hewan dan mikro-organisme dan dapat menunjukkan well being ecosystem. Konservasi keanekaragaman hayati pada dewasa ini, khususnya di daerah tropis lebih difokuskan pada ekosistem terestrial. Perhatian dan kepedulian terhadap kepunahan atau berkurangnya habitat maupun populasi organisme perairan masih rendah walaupun telah diketahui secara umum akibat kerusakan lingkungan yang ditimbulkan, baik fisik, kimia maupun biologi. Banyak faktor yang dapat mengancam kelestarian ekosistem perairan waduk, baik ancaman secara alami maupun akibat faktor anthrophogenik. Beberapa 
ancaman kepunahan ataupun penurunan populasi hayati perairan dapat dikategorikan sebagai berikut:

(1) Perubahan habitat. Perubahan sistem hidrologi sebagai akibat perubahan aliran sungai dan pembuatan bendungan dapat me mpengaruhi kelestarian keanekaragaman hayati perairan. Komposisi dan populasi ikan di perairan waduk pada dasarnya akan mengalami perubahan, yaitu penurunan jenis-jenis ikan rheophylic yang disebabkan akibat terjadinya perubahan habitat dari ekosistem mengalir ke ekosistem lacustrine.

(2) Introduksi jenis-jenis ikan eksotik (exotic species). Akibat introduksi jenis-jenis ikan eksotik dari kegiatan budidaya KJA cenderung akan mengganggu keseimbangan ekosistem dan mengeliminasi bahkan cenderung akan terjadi kelangkaan jenis-jenis ikan asli.

Jenis sumberdaya ikan di perairan waduk beragam dan termasuk dalam jenis ikan yang memiliki nilai ekonomi tinggi. Namun dengan adanya usaha KJA menyebabkan perubahan komposisi ikan dan ada beberapa jenis ikan yang mengalami kepunahan (Krismono, et al., 1983 dalam Tjahjo D.W.H, et al., 2008). Dugaan sementara bahwa ikan-ikan yang mengalami kepunahan disebabkan karena perubahan lingkungan perairan yang terjadi dan persaingan dalam memperebutkan makanan.

Salah satu pendekatan perubahan lingkungan perairan yang menyebabkan eutrofikasi yaitu melalui konsep beban nutrien (phosphorous loading) yaitu penambahan jumlah nutrien ke dalam suatu area perairan dalam suatu unit waktu tertentu. Dengan kata lain, menunjukkan adanya suatu hubungan antara jumlah nutrien yang masuk ke dalam badan air dan respon sistem perairan terhadap inputnya. Vollenweider (2000) dalam Sukimin (2008) menyatakan bahwa konsep beban nutrien awalnya merupakan aplikasi dari elemen seperti nitrogen dan phosphorous yang akan menentukan tingkat eutrofikasi dan pruduktivitas perairan, namun, diantara nutrien lainnya, phosphorous merupakan elemen yang paling penting dibandingkan nitrogen dalam mengendalikan eutrofikasi. Pengertian "environmental capacity" digunakan untuk menggambarkan kemampuan untuk memproduksi ikan melalui kegiatan budidaya namun lingkungannya tetap lestari. Beberapa hal yang perlu dipertimbangkan mengenai "environmental capacity" adalah:

Faktor yang menentukan produktivitas lingkungannya;

Pakan yang diberikan dan limbah yang dihasilkan dari kegiatan budidaya;

Bagaimana lingkungan akan merespon beban limbah yang dihasilkan;

Seberapa besar perubahan lingkungan yang dapat diperbolehkan

\section{Pola Pemanfaatan Perikanan Tangkap}

Berdasarkan data DKP dan ACIAR (2007) diperoleh bahwa jenis ikan yang tertangkap di Waduk Jatiluhur didominasi oleh ikan nila (79-96\%), ikan mas, patin sius dan gabus. Selain itu juga ditemukan jenis ikan oscar, kongo dan goldsom yang tidak disukai nelayan dan termasuk jenis ikan yang tidak ekonomis. Ikan-ikan tersebut sering disebut hama karena sifat berkembang biak yang sangat tinggi sehingga ikan-ikan ekonomis lainnya semakin terdesak dengan keberadaan ikan hama tersebut. Pengolahan ikan non ekonomis tersebut dilakukan dengan cara dijemur hingga kering, baru kemudian dijual ke konsumen. Hasil tangkapan ikan di Waduk Jatiluhur bervariasi antara 74.674-148.024 kg/bulan dengan rata-rata $118.875 \mathrm{~kg} / \mathrm{bulan}$ atau total tangkapan ikan sebesar 1.359,439 ton/tahun. Di Waduk Cirata hasil tangkapan ikan berfluktuasi antara 25.131-36.805 kg/bulan dengan rata-rata $29.637 \mathrm{~kg} / \mathrm{bulan}$ atau 344,969 ton/tahun. Pemerintah pusat melalui Departemen Kelautan Perikanan (DKP) telah melakukan 
Tabel 5. Komposisi Hasil Tangkapan Bulan Mei-Juli 2009 (Trianto -unpublished, 2009)

Table 5. Catch Composition Species of Fish During May - July 2009 (Trianto - unpublished, 2009)

\begin{tabular}{cll}
\hline No & Jenis Ikan/Species of Fish & Nama IImiah/Scientific Name \\
\hline 1 & Oscar & Amphilophus citrinellus \\
2 & Kaca & Chanda punctulata \\
3 & Golsom & Parachromis nanaguensis \\
4 & Nila & Oreochromis niloticus \\
5 & Patin & Pangasionodon hypopthalmus \\
6 & Kebo geran g & Mystus negriceps \\
7 & Lalawak & Barbodes bramoides \\
8 & Hampala & Hampala macrolepidota \\
9 & Beunter & Puntius binotatus \\
10 & Seren & Cyclocheilichtys enoplos \\
11 & Sepat & Trichogaster trichopterus \\
\hline
\end{tabular}

Sumber: Trianto-tidak dipubikasikan (2009)/Source:Trianto-unpublished (2009)

kebijakan berupa penebaran benih ikan nila maupun bandeng ke Waduk Jatiluhur dalam rangka meningkatkan pendapatan nelayan.

Komposisi ikan setelah adanya KJA yang berkembang pesat (diduga adalah jenis ikan yang masuk bersama benih ikan yang dibudidayakan yang selanjutnya terlepas ke perairan dan dapat berkembang dengan baik karena adanya ketersediaan makanan yang ada di perairan waduk). Hasil pengamatan ikan-ikan yang tertangkap pada bulan Mei-Juli 2009 tertera dalam Tabel 5. (Trianto, 2009, unpublished). Populasi ikan hasil tangkapan oleh nelayan di Waduk Jatiluhur saat ini didominasi oleh ikan oscar dan golsom, namun jenis ikan tersebut secara ekonomis nilainya sangat rendah bila dibandingkan dengan ikan mas dan nila.

Struktur komunitas ikan-ikan di wadukwaduk kaskade di Sungai Citarum saat ini cenderung sudah terjadi perubahan dibandingkan dengan pada awal penggenangan dan pembuatan waduk-waduk di Sungai Citarum. Struktur komunitas ikanikan pada saat ini di Waduk Jatiluhur cenderung didominansi oleh jenis-jenis ikan introduksi, yaitu Ciclosoma nitrinellum dan Astronotus ocellatus (Fam. Cichlidae), Chanos chanos (Fam. Chanidae), Colosoma macropomum (Charachidae) dan Oxyeleotris marmorata (Eleotridae), sedangkan Waduk Cirata ditemukan jenis C. nitrinelum (Fam Cichlidae), Chanos-chanos (Fam. Chanidae), O.marmorata dan Hyposarcus pardalis (Fam. Eleotridae) dan C. macropomum (Charachidae). Beberapa jenis ikan rheophilic di Waduk Jatiluhur pada tahun 1967-1979 masih banyak tertangkap beberapa jenis ikan asli seperti ikan jambal (Pangasius pangasius/Fam Pangasidae)) dan balidra (Notopterus chitala/Fam Notopteridae), dimana saat ini ikan-ikan tersebut sudah jarang ditemukan (Trianto, 2009, unpublished).

Sementara berdasarkan data DKP dan ACIAR (2007), jenis alat tangkap ikan yang digunakan nelayan di Waduk Jatiluhur yaitu jaring insang, jala, anco dan pancing. Namun, saat ini nelayan umumnya menggunakan alat tangkap jaring insang dan jala (Tabel 6), dengan perahu kayu yang dilengkapi motor tempel ataupun tanpa motor tempel dan rakit 
Tabel 6. Jumlah Nelayan dan Alat Tangkap di Waduk Jatiluhur.

Table 6. Number of Fisher and his/her Fishing Unit in the Jatiluhur's Reservoir.

\begin{tabular}{ccccc}
\hline No & $\begin{array}{c}\text { Jenis Alat Tangkap / } \\
\text { Fishing unit }\end{array}$ & $\begin{array}{c}\text { Aktif / } \\
\text { Active }\end{array}$ & $\begin{array}{c}\text { Pasif / } \\
\text { Pasive }\end{array}$ & $\begin{array}{c}\text { Jumlah Nelayan / } \\
\text { No of fisher }\end{array}$ \\
\hline 1 & Gillnet & 2,175 & 0 & 665 \\
2 & Jala/Cast net & 241 & 0 & 242 \\
& Jumlah/Total & $\mathbf{2 , 4 1 6}$ & $\mathbf{0}$ & $\mathbf{9 0 7}$ \\
\hline
\end{tabular}

Sumber: DKP dan ACIAR (2007)/Source: MMAF and ACIAR (2007).

bambu. Alat tangkap gillnet relatif lebih banyak digunakan nelayan karena efisien dalam penangkapan ikan. Hal ini dikarenakan ikanikan hasil tangkapan biasanya berukuran kecil yang sesuai dengan mata jaring gillnet.

Pengelolaan perikanan tangkap meliputi berbagai kegiatan yang ditujukan untuk memanfaatkan sumberdaya perikanan secara optimal dan berkelanjutan. Pola pemanfaatan sumberdaya perairan untuk kegiatan perikanan tangkap, umumnya berdasarkan pada tinggi muka air oleh badan otorita dan curah hujan. Pada saat air muka tinggi, nelayan menggunakan alat tangkap berukuran kecil (mata jaring $\pm 1,5$ inci), sehingga ikan yang tertangkap adalah ikan yang ukurannya kecil dan melimpah. Sedangkan pada saat air muka rendah (air mengumpul di tengah), nelayan menangkap ikan menggunakan alat tangkap berukuran besar (mata jaring \pm 3 inci), sehingga ikan yang tertangkap adalah ikan yang ukurannya besar (> 500 gram). Namun pada saat ini nelayan tidak menghiraukan ukuran alat tangkap yang ideal digunakan sesuai dengan tinggi muka air tersebut, sehingga menyebabkan kepunahan sumberdaya ikan di perairan waduk.

\section{Pola Pemanfaatan Perikanan Budidaya Keramba Jaring Apung (KJA)}

Kegiatan perikanan budidaya yang dilakukan di Waduk Djuanda adalah perikanan budidaya menggunakan keramba jaring apung (KJA). Jenis ikan yang umumnya dibudidayakan adalah jenis ikan mas, nila dan patin. Petak KJA yang digunakan memiliki ukuran $7 \times 7$ meter dengan kepemilikan jumlah petak KJA yang terus mengalami peningkatan pesat dari tahun ke tahun (Tabel 7).

Tabel7. Perkembangan Jumlah Budidaya Keramba Jaring Apung (KJA) di Waduk Jatiluhur (2002-2007).

Table 7. Development Number of Floating Cage Culture Technology (KJA) in Jatiluhur's Reservoir.

\begin{tabular}{|c|c|c|c|c|c|c|}
\hline \multirow[b]{2}{*}{$\begin{array}{c}\text { Tahun / } \\
\text { Year }\end{array}$} & \multirow[b]{2}{*}{$\begin{array}{l}\text { Bulan / } \\
\text { Month }\end{array}$} & \multirow[b]{2}{*}{$\begin{array}{c}\text { Petak/ } \\
\text { No. of cage }\end{array}$} & \multicolumn{3}{|c|}{ Petak / Cage } & \multirow[b]{2}{*}{$\begin{array}{l}\text { ljin Petak / } \\
\text { Licensed }\end{array}$} \\
\hline & & & $\begin{array}{l}\text { Aktif / } \\
\text { Active }\end{array}$ & $\begin{array}{l}\text { Pasif / } \\
\text { Pasive }\end{array}$ & $\begin{array}{l}\text { Rusak / } \\
\text { Damage }\end{array}$ & \\
\hline 2002 & $\begin{array}{l}\text { Januari } \\
\text { Desember } \\
\text { Januari }\end{array}$ & $\begin{array}{l}2.159 \\
2.159 \\
2.159\end{array}$ & $\begin{array}{l}409 \\
565 \\
150\end{array}$ & $\begin{array}{r}1.750 \\
957 \\
1.358\end{array}$ & $\begin{array}{r}- \\
653 \\
653\end{array}$ & $\begin{array}{l}319 \\
319 \\
203\end{array}$ \\
\hline $\begin{array}{l}2003 \\
2007\end{array}$ & $\begin{array}{l}\text { Agustus } \\
\text { Desember } \\
\text { Januari }\end{array}$ & $\begin{array}{l}3.216 \\
3.216 \\
8.043\end{array}$ & $\begin{array}{r}645 \\
363 \\
4.975\end{array}$ & $\begin{array}{l}1.818 \\
2.853 \\
3.068\end{array}$ & $\begin{array}{r}653 \\
- \\
-\end{array}$ & $\begin{array}{r}219 \\
363 \\
-\end{array}$ \\
\hline
\end{tabular}

Sumber: Sudjana (2004); DKP dan ACIAR (2007) /Source: Sudjana (2004); MMAF and ACIAR (2007). 
Jaring dipasang dengan menggunakan tali dari tiap ujung jaring dengan pengait pada tiap sudut kolam yang dipasangi pemberat (3 Kg). Ukuran mata jaring disesuaikan dengan ukuran benih dan ukuran pada saat panen. Untuk pendederan benih (5-10 gram) digunakan mata jaring 0,75 inci, untuk pembesaran ikan (10 gram-panen) digunakan mata jaring 1 inci. Pembudidaya yang menggunakan sistem double layer (jaring ganda), maka ukuran mata jaring terluar (jaring kolor) digunakan 1,25 inci.

Lokasi KJA Waduk Jatiluhur telah ditetapkan berdasarkan Keputusan Bupati Kabupaten Purwakarta No. 532.32/Kep.234Diskan/2000 dibagi dalam 7 zona, sedangkan PJT II menetapkan 6 zona. Posisi penempatan KJA di Waduk Jatiluhur harus mempertimbangkan luas zona yang diijinkan yaitu maksimal $1 \%$ dari luas efektif waduk, elevasi minimal 87.65 meter dpl, kedalaman air minimal 10 meter, arah gelombang dominan, jarak antar unit KJA 50 meter, letak pemasangan jangkar, batas antar blok/unit dan pencemaran.

Pola pemanfaatan kegiatan budidaya dapat dibagi menjadi dua berdasarkan skala usaha, yaitu pembudidaya skala kecil yang berada di zona 3, 4 dan 5 serta pembudidaya skala besar yang berada di zona 4 dan 5 . Pembudidaya skala kecil memiliki rata-rata 6-12 petak/RTP dimana sebagian besar mengelola sendiri usaha budidayanya dengan menggunakan modal sendiri. Pola budidaya dilakukan dengan sistem setengah musim jenis ikan patin dan nila. Sistem setengah musim berarti bahwa pembudidaya hanya membesarkan sampai pada ukuran tertentu untuk kemudian dijual kembali kepada pemodal besar.

Benih, pakan dan tenaga kerja merupakan input produksi yang penting untuk diperhitungkan pembudidaya. Rata-rata jumlah benih ikan patin yang dibutuhkan berkisar antara 2.000-2.500 ekor/petak ukuran benih 1 inci dengan harga sekitar Rp. 100/ekor. Sedangkan jumlah benih ikan nila yang dibutuhkan berkisar antara 10.00020.000 ekor/petak (jaring kolor). Dari jumlah tersebut, maka secara umum total benih yang dibutuhkan sekitar 100-150 juta ekor benih per musim tanam atau 300 juta - 450 ekor benih per tahun (Tjahjo D.W.H et.al, 2008). Jenis pakan yang digunakan pembudidaya adalah pakan turbo, namun ada sebagian pembudidaya menggunakan pakan campuran antara mie bekas, roti bekas, singkong, dan pelet. Jumlah pakan yang dibutuhkan dapat mencapai 3 ton/musim. Selama periode budidaya, pakan turbo yang dibutuhkan sebesar 1 kwintal pellet (bulan 1 pembesaran), dan 2-2,5 ton pakan jenis mie, roti dan singkong rucah. Pada saat ini harga pakan jenis turbo mencapai Rp. 260.000/sak (Rp. 5.200/kg). Untuk budidaya jenis nila, sebagian besar petani menggunakan pakan dari jenis mie bekas, roti bekas, dan singkong. Dalam satu periode budidaya (3-6 bulan) dapat menghabiskan pakan kurang lebih 2,2 ton pakan dengan perbandingan mie dan roti $1,5: 0,7$. Pada saat ini harga kedua jenis pakan tersebut masih cukup murah, yakni berkisar antara Rp. 1.750-3.000/kg untuk mie bekas, dan Rp. 2.750 untuk roti bekas. Tenaga kerja yang dibutuhkan umumnya antara 2-7 orang dengan gaji berkisar antara Rp. 400.000-600.000/bulan, ditambah penghasilan lain (saat panen) dengan kisaran nilai antara Rp. 200.000-250.000/panen.

Selain digunakan untuk pembudidaya kecil, zona 4 dan 5 juga digunakan untuk budidaya KJA intensif dengan jenis ikan yang dibudidayakan adalah patin, nila dan mas. Jumlah benis ikan mas yang dibutuhkan berkisar antara 10.000-20.000 ekor/petak yang dapat menghasilkan ikan antara 1-1,8 ton/petak/musim. Sedangkan untuk jenis patin, dibutuhkan benih sebanyak 13.000 ekor/petak yang dipelihara selama 12 bulan dengan pakan dapat mencapai 5 ton dan dapat menghasilkan sebanyak 6.5-7 ton/musim. Sementara itu ikan nila dibudidayakan pada lapisan bawah dengan jumlah benih yang dibutuhkan antara 
12.000-20.000 ekor/petak yang dibesarkan selama 6 bulan dan dapat menghasilkan sebanyak 1-2 ton/kolor/musim.

Pola pemanfaatan sumberdaya perairan waduk untuk kegiatan perikanan budidaya, berdasarkan tinggi muka air. Pada saat muka air tinggi adalah kondisi optimum operasional, dalam hal ini pembudidaya ikan akan mengisi seluruh petak yang dimiliki sedangkan pada saat muka air rendah, pembudidaya ikan hanya mengisi sebagian kecil petak yang dimilikinya. Namun kondisi di lapangan tidak demikian, pembudidaya ikan cenderung mengabaikan tinggi muka air dan hanya berorientasi pada produksi perikanan. Dalam hal ini, pembudidaya ikan tidak berpikir tentang kelangsungan sumberdaya itu sendiri dan dampaknya pada lingkungan perairan. Pada saat kondisi permukaan air surut maka kualitas air cenderung menurun, sehingga disarankan untuk mengurangi padat tebar ikan dan jumlah pakan yang diberikan.

Produksi ikan dari kegiatan budidaya dari tahun 2004 sampai dengan 2007 mengalami kenaikan yaitu dari 7.048,36 ton menjadi 33.314 ton (Tabel 8). Produksi ikan yang terus menerus naik dan jumlah petak yang tidak terkendali berimbas juga pada kondisi lingkungan (terjadi eutrofikasi yang berlebihan) dan penurunan kualitas air. Tingginya produksi ikan tidak sebanding dengan kerusakan sumberdaya di perairan waduk.
Kendala yang dihadapi oleh pembudidaya adalah keterbatasan modal yang dimiliki. Hal ini dapat terlihat bahwa jumlah KJA yang aktif hanya berkisar antara $70-80 \%$ per RTP. Selain itu, pembudidaya yang nakal sering menurunkan jaring budidayanya (amplehan) dengan harapan ikan-ikan non budidaya dapat terjaring. Hal ini dapat memicu kemarahan dari nelayan penangkap ikan, karena pendapatan dari menangkap ikan telah berkurang. Dampak secara psikologis antara pembudidaya dengan penangkap ini jika tidak segera ditangani bisa saja menimbulkan kesenjangan sosial yang pada akhirnya bisa menimbulkan konflik. Kendala lainnya adalah belum ditemukannya formula obat yang tepat untuk menangani penyakit ikan yang disebabkan oleh virus, sehingga usaha budidaya ini menjadi sangat beresiko. Hal tersebut dikarenakan jika virus sudah menyerang salah satu dari pembudidaya, maka dapat dipastikan pembudidaya lainnya akan terkena dampak dari virus tersebut.

Pada dewasa ini kegiatan budidaya ikan KJA di perairan waduk kaskade Sungai Citarum meningkat dengan cepat, terutama untuk budidaya ikan mas (Cyprinus carpio) dan ikan Nila (Oreochromis nilotica). Berdasarkan hasil pengamatan BBAT-ACIAR (2005) dalam DKP-ACIAR (2007) jumlah KJA di Waduk Jatiluhur adalah 4.976 unit (4.557 unit aktif beroperasi). Beberapa penelitian

Tabel 8. Produksi Perikanan Budidaya Keramba Jaring Apung di Waduk Jatiluhur.

Table 8. Fish Production of the Floating Cage Culture Technology in the Jatiluhur's Reservoir, 2004-2007.

\begin{tabular}{cc}
\hline Tahun /Year & $\begin{array}{c}\text { Produksi (ton)/ } \\
\text { Production (ton) }\end{array}$ \\
\hline 2004 & $7,048.36$ \\
2005 & $12,972.58$ \\
2006 & $15,036.50$ \\
2007 & $33,314.00$ \\
\hline
\end{tabular}

Sumber: Dinas Peternakan dan Perikanan Purwakarta (2005-2008)/

Source: Fisheries and Livestock Services of Purwakarta Distict (2005-2008). 
telah melaporkan dampak kegiatan budidaya KJA secara intensif dapat menyebabkan perubahan tingkat status trofik perairan. Kegiatan budidaya KJA dapat meningkatkan pendapatan masyarakat dari sektor perikanan, selain meningkatkan produksi perikanan juga memberikan lapangan kerja untuk masyarakat yang tinggal di sekitar waduk di perairan umum.

Namun dampak negatif kegiatan budidaya KJA terutama berasal dari particulate dan nutrien terlarut yang dihasilkan dari ekskresi hewan (ikan) dan pakan yang tidak dimakan dapat meningkatkan unsur hara di perairan. Penentuan lokasi dan semua kegiatan budidaya ikan terhadap daya dukung lingkungannya (carrying capacity of the environment) merupakan faktor yang sangat penting dalam mengurangi ecological effect dan timbulnya risiko yang lebih luas terhadap lingkungannya. Model phosphorous budget telah ditetapkan oleh Vollenweider dan selanjutnya Beveridge (1996) dalam Sukimin (2008) mengembangkan model daya dukung perairan untuk kegiatan budidaya ikan berdasarkan beban limbah phosphorous dari hasil penelitiannya terhadap budidaya ikan salmon dalam hubungannya antara beban limbah phosphorous dan kandungan chlorophyl-a yang dihasilkan di perairan. Model beban limbah phosphorous dapat digunakan untuk pendugaan daya dukung perairan untuk menghasilkan produksi ikan dimana kualitas lingkungan perairannya tetap terjaga dan masih dalam batas yang diterima (acceptable limits).

Konsep beban nutrien (phosphorous loading) adalah bertambahnya jumlah nutrien ke dalam suatu area perairan dalam suatu unit waktu tertentu. Dengan kata lain, menunjukkan adanya suatu hubungan antara jumlah nutrien yang masuk ke dalam badan air dan respon sistem perairan terhadap inputnya. Vollenweider menyatakan bahwa konsep beban nutrien awalnya merupakan aplikasi dari element seperti nitrogen dan phosphorous yang akan menentukan tingkat eutrofikasi dan pruduktivitas perairan. Namun diantara nutrien lainnya, phosphorous merupakan element yang paling penting dibandingkan nitrogen dalam mengendalikan eutrofikasi. Pengertian "environmental capacity" digunakan untuk menggambarkan kemampuan untuk memproduksi ikan melalui kegiatan budidaya namun lingkungannya tetap lestari.

Seberapa besar perubahan lingkungan yang dapat diperbolehkan dapat dilihat dari beberapa hal yang perlu dipertimbangkan mengenai "environmental capacity" diantaranya adalah:

- Faktor yang menentukan produktivitas lingkungannya

- $\quad$ Pakan yang diberikan dan limbah yang dihasilkan dari kegiatan budidaya

- Bagaimana lingkungan akan merespon beban limbah yang dihasilkan

\section{Eksternalitas Pengelolaan Kegiatan Perikanan}

Pola pemanfaatan sumberdaya perikanan yang menjadi penyebab timbulnya eksternalitas dapat dibagi menjadi lima kategori pemanfaatan yang saling mempengaruhi, yaitu perikanan tangkap, perikanan budidaya, wisata pemancingan, transportasi dan manajemen waduk (Tabel 9). Pada dasarnya eksternalitas yang dimaksud dalam penelitian ini tidak hanya eksternalitas negatif, namun hasil dari pengamatan di lapangan lebih sering ditemukan eksternalitas yang mengarah pada negatif. Pemanfaat perikanan tangkap dan perikanan budidaya memberikan kontribusi yang cukup besar terhadap kegiatan eksternalitas yang terjadi.

Eksternalitas yang umum dilakukan oleh pemanfaat perikanan tangkap adalah penggunaan alat dan teknis yang tidak ramah lingkungan, dimana hal tersebut akan menimbulkan kerugian jangka panjang diantara sesama pemanfaat perikanan tangkap. Penggunaan mata jaring yang terlampau kecil oleh nelayan akan menyebabkan kepunahan dari beberapa jenis ikan. Ikan maupun udang-udangan yang 


\section{Tabel 9. Eksternalitas yang teridentifikasi pada pelaku kegiatan usaha pada perikanan di Waduk Jatiluhur.}

Table 9. Identified Externality of Resource Users in the Jatiluhur's Reservoir Fishery.

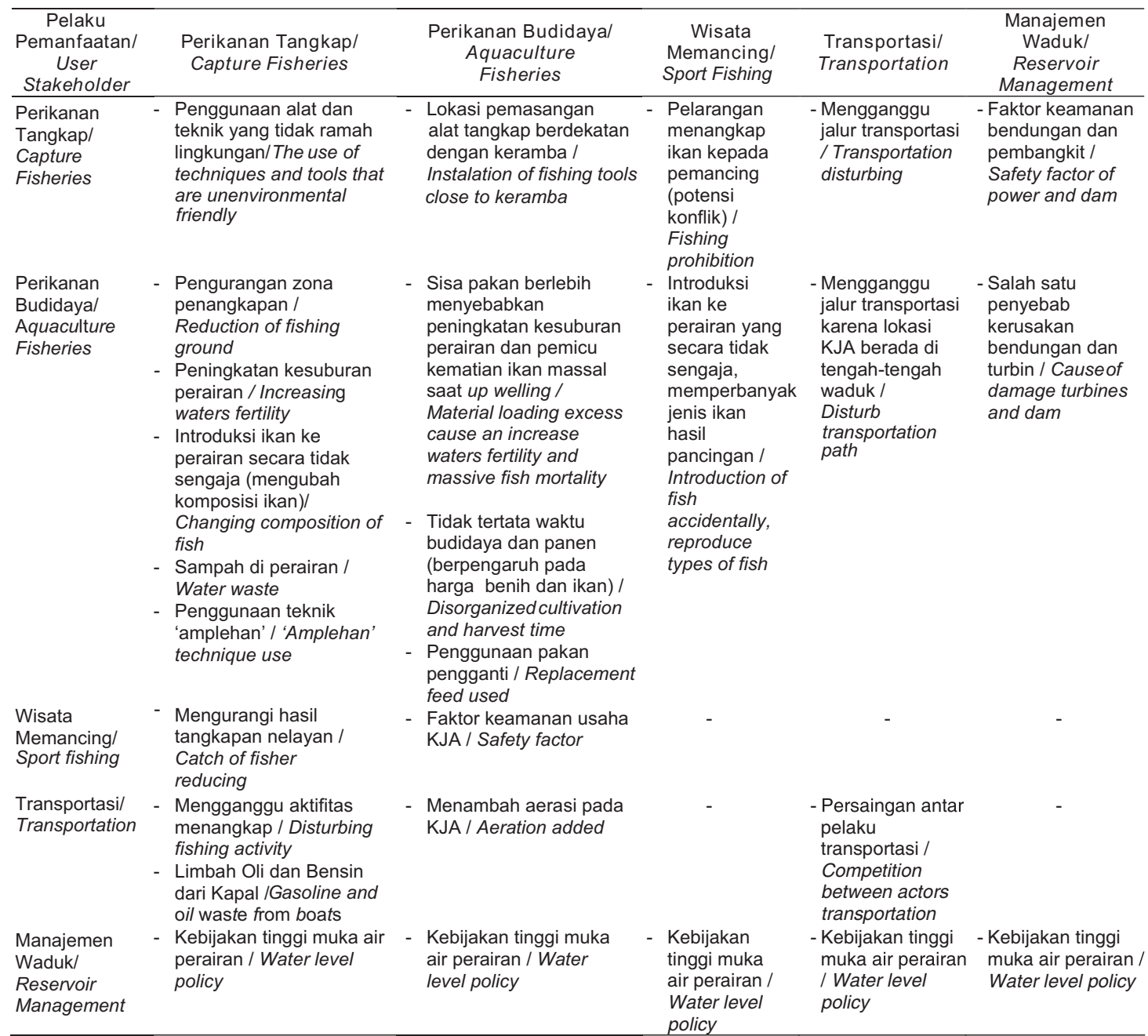

Sumber: Data Primer, 2009 / Source: Primary data, 2009.

hilang tersebut terjadi karena ikan-ikan kecil sebagai bakal calon ikan dewasa sudah terlebih dahulu tertangkap sebelum mencapai ukuran konsumsi. Hal tersebut tentu saja merugikan bagi nelayan itu sendiri. Selain itu biaya untuk menangkap ikan tidak sebanding dengan hasil yang didapat karena nilai ekonomis (produksi) dari penangkapan tidak tinggi lagi.
Kegiatan perikanan budidaya yang menimbulkan eksternalitas bagi perikanan tangkap salah satunya adalah pemanfaat perikanan budidaya melakukan teknik "amplehan". "Amplehan" merupakan penangkapan ikan non budidaya dengan cara menurunkan jaring. Teknis "amplehan" merupakan salah satu cara yang dilakukan dalam rangka meminimalkan biaya input 
produksi (benih) maupun meminimalkan biaya tenaga kerja. Antar pemanfaat perikanan budidaya sendiri yang sering terjadi eksternalitas adalah material loading pakan yang berlebih. Hal tersebut seringkali dikaitkan dengan kematian massal ikan yang setiap tahun terjadi. Namun kegiatan eksternalitas yang harus diwaspadai sekarang adalah adanya potensi konflik antara pemanfaat perikanan tangkap dengan wisata pemancingan akibat dari persepsi bahwa ikanikan yang ada di waduk milik nelayan.

\section{Status Keberlanjutan sumberdaya Perikanan di Waduk Jatiluhur}

Tujuan akhir pengelolaan perikanan di waduk adalah untuk meningkatkan dan mempertahankan produksi perikanan dalam keadaan yang sustainable dalam pengertian mempertahankan manfaat ekonomi, sosiopolitik dan kesesuaian daya dukung dan daya tampung lingkungan sumberdaya, baik untuk generasi sekarang maupun generasi yang akan datang. Hal tersebut dapat dilakukan dengan menerapkan pola pemanfaatan perikanan tangkap dan budidaya sesuai dengan kaidah ataupun prinsip-prinsip yang telah direkomendasikan.

Perubahan ekosistem waduk sangat berpengaruh terhadap populasi ikan alami. Pengelola perikanan diharapkan mampu untuk mengendalikan jenis ikan yang tidak disukai, melakukan penebaran dan introduksi yang sesuai dengan kondisi lingkugan, pengaturan tinggi rendahnya permukaan air dan pencegahan serta pengendalian hama penyakit dan parasit ikan. Terkait dengan pengelolaan penangkapan ikan, teknik penangkapan yang diterapkan harus berdasarkan pada teknologi tepat guna yaitu teknologi yang sederhana, mudah diterapkan, tidak memerlukan rancang bangun yang tinggi, produktivitasnya tinggi namun tidak merusak sumberdaya perikanan. Widana dan Martosubroto (1986) memberikan beberapa alternatif bagaimana mengelola penangkapan ikan, diantaranya adalah:
1. Pembatasan baik jumlah alat tangkap maupun musim penangkapan

2. Pembatasan ukuran mata jaring atau alat lain

3. Meningkatkan fungsi reservat yang telah ada

4. Mengadakan restocking yang ditunjang dengan penyediaan benih yang cukup

5. Diversifikasi usaha ke bidang lain

6. Perlunya penyuluhan yang rutin kepada pelaku perikanan mengenai pentingnya kelestarian sumberdaya

Keberlanjutan perikanan tangkap dapat dilihat dari kondisi hasil tangkapan nelayan (indikator ekologi), pendapatan yang diterima nelayan (indikator ekonomi), hak nelayan dalam menangkap ikan (indikator sosial) dan keberadaan organisasi atau kelompok nelayan (indikator kebijakan). Dari keempat indikator tersebut memang ada yang memiliki tren positif, negatif maupun konstan. Sehingga masing-masing indikator memiliki keberlanjutan yang tidak seragam.

Pola pengelolaan perikanan budidaya agar efisien menurut Krismono (1995) adalah jenis perairan yang sesuai dengan jenis ikan yang dibudidayakan, letak dan lokasi KJA di tempat yang tidak terjadinya umbalan dan tidak melakukan penanaman pada saat musim-musim dimana kondisi air rendah. Selain itu faktor kemudahan jangkauan dan ketersediaan sarana dan prasarana serta keamanan di waduk mutlak diperlukan.

Keberlanjutan perikanan budidaya dapat dilihat dari hasil produksi pembudidaya (indikator ekologi), pendapatan yang diterima pembudidaya (indikator ekonomi), konflik yang terjadi (indikator sosial), dan keberadan organisasi atau kelompok pembudidaya (indikator kebijakan). Berdasarkan penjelasan sebelumnya bahwa hasil produksi budidaya KJA cenderung meningkat. Begitu pula pendapatan yang diterima pembudidaya akan meningkat apabila pembudidaya dapat meminimalkan biaya dan mengurangi dampak dari kematian massal ikan. Terkait dengan konflik yang terjadi biasanya terdapat 
persaingan antar sesama pembudidaya ikan yang menjadi penampung. Namun konflik tersebut dapat diminimalkan dengan adanya pertemuan-pertemuan membahas segala permasalahan dalam forum kelompok pembudidaya.

Salah satu cara agar keberlanjutan perikanan di Waduk Jatiluhur tercapai yaitu dengan cara pengendalian blooming algae. Penelitian tentang cara-cara pemberantasan blooming algae baik secara mekanis, kimiawi dan biologis bertujuan untuk mencegah kematian dan hilangnya beberapa jenis ikan yang mempunyai nilai ekonomis penting dan jenis-jenis indigenous. Usaha pertama dalam pengendalian blooming algae adalah memanfaatkan algae untuk berbagai keperluan. Tetapi apabila populasi algae sedemikian besar, sehingga pengendalian dengan cara pemanfaatan ini belum mencapai tingkat populasi yang diharapkan, maka harus diusahakan berbagai macam cara pengendalian.

Pengendalian secara mekanis terutama berupa pengangkutan gulma air secara massal ke tepi danau. Pada umumnya dapat dikatakan bahwa pengendalian secara mekanis dengan tenaga manusia biayanya cukup mahal. Cara mekanis ini tidak memberikan pengaruh residu dan bahkan merangsang kecepatan tumbuh kembali, oleh karenanya harus secara terus menerus dilakukan, sebab dengan pengurangan kepadatan akibat adanya pengendalian ini, secara tidak langsung memberikan kesempatan gulma untuk tumbuh kembali secara leluasa dan cepat. Pengendalian secara mekanis pada umumnya tidak efektif karena selain biaya yang mahal, akan tetapi hasilnya hanya bersifat sementara.

Pengendalian secara kimiawi dapat menimbulkan pengaruh sampingan yang merugikan, yaitu pencemaran lingkungan. Pencemaran terjadi akibat bahan beracun dan berbahaya dalam limbah lepas dan masuk ke lingkungan perairan sehingga terjadi perubahan kualitas lingkungan. Bahan pencemar yang masuk ke dalam lingkungan akan bereaksi dengan satu atau lebih komponen lingkungan. Apabila bahan pencemar berakumulasi terus menerus dalam lingkungan sehingga lingkungan tersebut tidak mempunyai kemampuan alami untuk menetralisir, akan mengakibatkan perubahan kualitas air. Bahan kimia tersebut selain mematikan gulma dapat pula mematikan atau mengurangi jasad-jasad renik makanan ikan dalam perairan, membahayakan tanaman budidaya serta masyarakat dan hewan piaraan maupun satwa liar yang menggunakan air bagi keperluan hidupnya.

Pengendalian secara biologis adalah pengendalian dengan menggunakan mahluk hidup secara alami, misalnya ikan sebagai sarana pengendalian. Pengendalian secara biologis berarti pengrusakan atau penghambatan terhadap suatu organisme oleh organisme lain. Cara ini menarik karena merupakan cara memanfaatkan alam untuk mengendalikan alam itu sendiri. Pada prinsipnya pengendalian pertumbuhan adalah menjadi tujuan pengendalian, yakni dikendalikannya pertumbuhan blooming algae sehingga tidak sampai merugikan, bahkan masih memberi manfaat sebagai perlindungan lainnya. Kelebihan cara pengendalian gulma dengan cara biologis, khususnya dengan menggunakan ikan dibandingkan cara-cara lainnya adalah: (1) penurunan kandungan oksigen terlarut di perairan yang biasanya terjadi setelah proses pengendalian dengan cara kimiawi maupun mekanis tidak terjadi; (2) tidak merusak produktivitas perairan; (3) menambah hasil ikan dari perairan tersebut; dan (4) bila keseimbangan alami tercapai, sangat mungkin bahwa sifat pengendalian itu permanen sehingga tidak perlu diulang lagi. Beberapa syarat bagi pengendalian gulma secara biologis adalah: (1) dapat memakan beberapa jenis tumbuhan, (2) daya pengendaliannya tinggi, (3) tidak merupakan saingan bagi organism lain di perairan, (4) mudah dikendalikan, (5) tidak menjadi hama, dan (6) secara ekonomis dapat menambah produktivitas perairan. 
Cara yang baik dalam pengendalian blooming algae adalah cara pengendalian menurut keperluannya, untuk menekan agar populasi senantiasa berada di bawah ambang ekonomi, yakni di bawah batas kerugian yang nyata secara ekonomis sehingga kelestarian waduk dapat dijaga. Hal yang penting adalah usaha pencegahan ini agar blooming algae yang mempunyai potensi merugikan dapat dicegah penyebarannya, agar tidak memasuki daerah baru dan menimbulkan masalah baru di tempat lain. Jenis ikan yang sangat efektif untuk pengendalian blooming algae adalah ikan mola, silver carp (Hypophthalmicichthys molitrix). Ikan mola berasal dari China dan masuk ke Indonesia tahun 1969. Pada tahun 2008 telah dilakukan introduksi ikan bandeng (chanos chanos) oleh Direktorat Jenderal Budidaya, DKP sebanyak 2.000.000 ekor yang bertujuan selain untuk meningkatkan produkasi perikanan, ikan bandeng (Chanos chanos) berfungsi juga sebagai biological control.

\section{Perspektif Kebijakan}

Setelah mengetahui eksternalitas yang terjadi di Waduk Jatiluhur, maka kebijakan yang dapat diambil adalah sangat terkait dengan penguatan hak kepemilikan diantara pelaku perikanan tangkap maupun perikanan budidaya. Pelaku perikanan tersebut sebenarnya telah mengetahui bahwa waduk sebagai lahan mencari nafkah keluarga mereka memiliki daya dukung. Kerusakan yang terjadi dapat dikurangi jika kita tahu persis siapa yang melakukan eksternalitas, sehingga pemberian hak kepemilikan akan meningkatkan manfaat ekonomi dari salah satu pihak dengan menurunkan manfaat ekonomi dari pihak lain.

Perikanan (fisheries enhancement) didefinisikan sebagai aktivitas yang ditujukan untuk menambah atau melestarikan rekrutmen satu atau lebih organisme perairan dan meningkatkan total produksi atau unsur produksi yang dipilih dari suatu perikanan yang masih berada di bawah tingkat lestari dari proses alaminya. Beberapa kegiatan yang dapat mencapai tujuan peningkatan perikanan antara lain adalah: (1) peningkatan dengan cara memodifikasi lingkungan akuatik, (2) peningkatan dengan penebaran (perikanan berbasis budidaya), (3) peningkatan dengan introduksi spesies berbasis trofik level, dan (4) peningkatan dengan pengelolaan perikanan .

Peningkatan stok ikan di perairan waduk pada umumnya ditujukan untuk meningkatkan hasil tangkapan ikan atau memperbaiki populasi ikan karena populasi ikan di perairan tersebut menurun. Penurunan populasi ikan tersebut dapat diakibatkan oleh beberapa faktor, antara lain adalah penangkapan yang intensif, perubahan habitat sehingga tidak sesuai untuk ikan-ikan asli untuk melakukan proses peremajaan, sumberdaya pakan dan relung ekologis yang tidak dimanfaatkan secara optimum. Peningkatan stok selain bertujuan untuk memperbaiki kuantitas dan kualitas stok ikan, sehingga hasil proses peremajaannya akan memperbaiki potensi reproduksi dapat pula berperan untuk melakukan kegiatan perikanan baru, yaitu dengan mengintroduksi jenis ikan tertentu dengan memanfaatkan habitat dan pakan yang belum dimanfaatkan oleh ikan yang sudah ada.

Hal yang paling penting dalam kegiatan peningkatan perikanan adalah menjaga kelestarian sumberdaya perairan dengan memperhitungkan daya dukung perairannya serta menggunakan jenis-jenis ikan yang dapat memanfaatkan tingkat trofik (trophic level) dari rantai makan yang terdapat dalam ekosistem perairan tersebut. Dengan kata lain adalah terdapat keseimbangan antara peningkatan produksi perikanan dengan upaya pengendalian ekosistem perairan, sehingga proses peremajaan (recruitment) dan proses keseluruhan daur hidupnya berjalan dengan sempurna, dimana terdapat jenis-jenis ikan yang dapat memanfaatkan energi (sumberdaya pakan) yang belum dimanfaatkan oleh organisme /ikan lainnya. Jenis-jenis ikan yang diharapkan mampu 
memanfaatkan niche yang masih belum dimanfaatkan oleh organisme akuatik lainnya dan juga berfungsi sebagai biological cleaning agents, selain ikan mola, antara lain adalah ikan bandeng, ikan nilem (Osteochilus hasellti), ikan tawes (Puntius javanicus) dan ikan nila (Oreochromis niloticus).

\section{IV.KESIMPULAN DAN IMPLIKASI KEBIJAKAN}

\section{Kesimpulan}

Produksi ikan perairan waduk berkembang pesat dengan diterapkannya usaha budidaya ikan dalam KJA. Pada tahap awal, usaha budidaya ikan tersebut memberikan manfaat ekonomi yang sangat nyata bagi pemilik modal maupun masyarakat sekitar; tetapi pada perkembangannya yang kurang atau tidak terkendali menimbulkan perubahan dinamika perairan waduk menjadi lebih subur sebagai akibat sisa pakan yang tidak termanfaatkan.

Eksternalitas yang terjadi sebagai akibat aktivitas perikanan membawa dampak positif maupun negatif kepada aktivitas perikanan sejenis maupun aktivitas perikanan tipe lainnya. Dampak negatif dapat direduksi dengan cara melakukan aktivitas usaha sesuai dengan pola yang direkomendasikan.

Dinamika kegiatan penangkapan ikan oleh nelayan dalam menggunakan alat tangkapnya sangat dipengaruhi oleh tinggi rendahnya permukaan air waduk. Perlu dilakukan pengaturan ukuran mata jaring bagi nelayan yang menggunakan alat tangkap gill net maupun cast net perlu untuk menjamin peremajaan dan pertumbuhan individu ikan secara alami. Pengaturan dalam bentuk penetapan zona juga diperlukan untuk mencegah terjadinya konflik antar pemanfaat sumberdaya.

Tingginya kesuburan perairan dapat berpengaruh terhadap fasilitas umur serta bendungan untuk menghasilkan tenaga listrik maupun pasokan air serta pengendali banjir. Selain itu, dapat memicu terjadinya 'umbalan' atau up-welling pada awal musim hujan yang pada tahap selanjutnya menyebabkan kematian ikan secara masal, terutama pada ikan-ikan yang dibudidayakan. Masalah kesuburan tersebut dapat diatasi secara biologi, yakni dengan melakukan penebaran (introduksi) jenis-jenis ikan yang dapat memanfaatkan unsur hara tersebut sebagai makanannya; dalam hal ini, telah diupayakan penebaran ikan nilem, nila dan bandeng. Penurunan produktivitas usaha budidaya ikan dapat disiasati dengan melakukan pengurangan jumlah ikan budidaya yang ditebar (stocking) atau memilih jenis ikan budidaya yang dapat memanfaatkan kesuburan perairan. Hal lain yang dapat dilakukan untuk menjamin terwujudnya eksternalitas positif dan keberlanjutan usaha budidaya ikan di KJA adalah dengan melakukan penjadualan atau pengaturan sistem periode budidaya (cropping system). Kebijakan pengurangan jumlah KJA secara bertahap sampai jumlah KJA yang direkomendasikan perlu dilaksanakan sehingga keberlanjutan usaha perikanan mampu memberikan eksternalitas positif dan lestari.

Keberlanjutan usaha perikanan di perairan waduk dapat dilakukan apabila manfaat ekonomi dirasakan oleh pelaku usaha serta masyarakat, secara sosial, budaya dan politik aktivitas yang ada dapat diterima oleh masyarakat setempat, pengelola maupun pemerintah daerah serta adanya kesesuaian daya dukung (carrying capacity) dan daya tampung lingkungan perairannya. Dalam konteks perikanan perairan di Waduk Jatiluhur, eksternalitas positif dan keberlanjutan kegiatan perikanan dapat terjamin bila melakukan pola usaha yang direkomendasinya, baik untuk kegiatan penangkapan, budidaya maupun pemancingan.

\section{Implikasi Kebijakan}

Implikasi kebijakan yang diperlukan agar mampu menjamin terwujudnya eksternalitas 
positif dan keberlanjutan usaha perikanan di perairan Waduk Jatiluhur adalah sebagai berikut: selama ini otoritas pengelola waduk, yaitu Perum Jasa Tirta II telah melakukan upaya-upaya ke arah pengurangan jumlah karamba jarring apung, antara lain dalam bentuk menarik karamba yang rusak ke darat, melakukan registrasi dan pembebanan sewa tempat usaha serta pembinaan kepada kelompok-kelompok pembudidaya binaan. Di lain pihak, Direktorat Jenderal Perikanan. Budidaya dan Dinas Perikanan telah melakukan penebaran jenis-jenis ikan yang direkomendasikan secara periodik. Keberlanjutan pengelolaan usaha perikanan ini tidak mungkin hanya dilakukan oleh pihak otoritas manajemen waduk bersama Dinas Perikanan setempat saja, tetapi yang lebih penting harus melibatkan masyarakat pemanfaat secara lebih luas. Dengan kata lain, model pengelolaan secara bersama (co-management) harus menjadi acuan utama pengelolaan nantinya.

Perairan waduk yang memiliki tingkat kesuburan tinggi berakibat negatif pada fasilitas dan umur pembangkit tenaga listrik, pada produktivitas usaha perikanan budidaya dan komposisi jenis dan ukuran ikan tertangkap. Oleh karena itu, implementasi strategi yang dapat mengurang penyebab kesuburan perairan serta menanggulangi masalah kesuburan perairan harus dilakukan secara simultan oleh pemerintah bersamasama dengan masyarakat. Pada kasus penebaran ikan, pemerintah harus melakukan inisiasi pembiayaan pengadaan benih ikan yang akan ditebar. Pada tahapan berikutnya menjadi tugas masyarakat (utama) dan pemerintah untuk memastikan bahwa ikan yang ditebar tersebut mampu memberikan manfaat sosial ekonomi bagi masyarakat. Manfaat bioekologi perlu dimonitor secara periodik sehingga implementasi kebijakan yang dilakukan tersebut dapat dievaluasi tingkat keberhasilan ataupun kegagalannya. Oleh karena itu, adanya kelembagaan penebaran ikan adalah vital untuk diwujudkan.
Implementasi strategi rasionalisasi jumlah dan intensitas budidaya ikan dalam KJA harus dilakukan pemerintah bersamasama dengan masyarakat sehingga konflik dapat diminimalisir dan target pewujudan eksternalitas positif dan keberlanjutan usaha perikanan di perairan waduk dapat tercapai.

\section{DAFTAR PUSTAKA}

Adibroto, T.A. dan Garno Y.S. 1999. Dampak Penggemukan Ikan di Badan Air Waduk Multiguna Pada Kualitas Air dan Potensi Waduk. Prosiding Semiloka Nasional Pengelolaan dan Pemanfaatan Danau dan Waduk. Bogor.

DKP-ACIAR, 2007. Culture,Capture and Conflicts: Sustaining Fish Production and Livelihood in Indonesia Reservoirs. Organized by ACIAR (Australian Center for International Agricultural Research) and Directorate General of Aquaculture, Ministry of Marine Affairs and Fisheries (MMAF).

Dinas Peternakan dan Perikanan Kabupaten Purwakarta. 2004. Statistik Peternakan dan Perikanan Tahun 2004. Dinas Peternakan dan Perikanan Kabupaten Purwakarta. Purwakarta. 2005. Statistik Peternakan dan

Perikanan Tahun 2005. Dinas Peternakan dan Perikanan Kabupaten Purwakarta. Purwakarta.

2006. Statistik Peternakan dan

Perikanan Tahun 2006. Dinas Peternakan dan Perikanan Kabupaten Purwakarta. Purwakarta.

2007. Statistik Peternakan dan

Perikanan Tahun 2007. Dinas

Peternakan dan Perikanan Kabupaten Purwakarta. Purwakarta.

2008. Statistik Peternakan dan

Perikanan Tahun 2008. Dinas Peternakan dan Perikanan Kabupaten Purwakarta. Purwakarta.

Fauzi, A. 2004. Ekonomi sumberdaya Alam dan Lingkungan Teori dan Aplikasi. PT Gramedia Pustaka. Jakarta. 
Friedman, D. 1990. Price theory: An Intermediate Text. South Western Publishing Co.

Hartwick, J.M. and N.D. Olewiler. 1998. The Economics of Natural Resource Use. Addison-Wesley Educational Publishers Inc. reading. Massachussetts.

Koeshendrajana, S. 2007. Tipologi

Sumberdaya Kelautan dan Perikanan: Isu dan Permasalahan. Dinamika Pengelolaan Sumberdaya Kelautan dan Perikanan : Bunga Rampai Hasil-hasil Riset : 1-16. Balai Besar Riset Sosial Ekonomi Kelautan dan Perikanan, BRKP-DKP. Jakarta. 136 hal.

Krismono, 1995. Penataan Ruang Perairan Umum untuk Mendukung Agribisnis dan Agroindustri. Prosiding Simposium Perikanan Indonesia I Tanggal 25-27 Agustus 1995. Jakarta.

Kula, E. 1992. Economics of Natural Resources and Environment. Chapman \& Hall, London.

Nasution, Z, et al. 2008. Laporan Teknis Panel

Perikanan Nasional. Jakarta: Badan Riset Kelautan Perikanan.

Prihadi, T. H. 2004. Upaya Perbaikan Lingkungan Untuk Menunjang Kesinambungan Budidaya Ikan dalam KJA. Makalah disampaikan pada Lokakarya Pemecahan Masalah Budidaya Ikan dalam KJA di perairan Waduk. Bogor.

Sudjana, T. 2004. Kebijakan Perum Jasa Tirta
II dalam Pengelolaan dan Pemanfaatan Waduk Ir. H. Djuanda untuk Perikanan Budidaya. Makalah Lokakarya Pemecahan Masalah Budidaya Ikan dalam KJA di Perairan Waduk. Bogor.

Sukimin,S. 2008. The application of a phosphorus loadings model estimating the carrying capacity for cage culture and its productivity of Saguling Reservoir, West Java, Indonesia. Proceeding on International Conference on Indonesian Inland Waters. Ministry of Marine Affairs and Fisheries. Palembang.

Tjahjo, D.W.H, Mujiyanto, dan Purnamaningtyas, S.E, 2008. Peremajaan Ikan yang Terlepas dari Budidaya Ikan dalam Keramba Jaring Apung di Waduk Ir. H. Djuanda. Prosiding Forum Nasional Pemacuan Sumberdaya Ikan I. Pusat Riset Perikanan Tangkap, BRKP, DKP. Jakarta.

Trianto. 2009. Struktur Komunitas Ikan di Waduk Jatiluhur. Tidak dipublikasi.

Widana, K. dan P. Martosubroto. 1986. Pengelolaan Perikanan Perairan Umum dan Masalahnya.Prosiding Seminar Perikanan Perairan Umum. Jakarta. 